\title{
THE USE OF SNAKES AND LADDERS GAMES IN TEACHING VOCABULARY
}

\author{
Titi Rohayati ${ }^{1}$, Andini Sufi Rizkyanti \\ ${ }^{1}$ IKIP Siliwangi \\ ${ }^{2}$ IKIP Siliwangi \\ ${ }^{1}$ titirochayati16@gmail.com, ${ }^{2}$ rizkyantiandinisufi@gmail.com
}

\begin{abstract}
The aim of this research is to know the response of students toward the use of snakes and ladders games in teaching vocabulary. To learning vocabulary in English lesson can be fun or bored for students so the purpose of the use this game is that the students can improve their english vocabulary with games method which can make motivate the students to learning. Meanwhile, the observed population that was used for the research was the sixth grade students of SDN 2 Ngamparah Padalarang. The writer used the descriptive qualitative methods. Snakes and ladders games can provide learning motivation to students to always learn or repeat the material that has been studied before which will be tested through games, so that it feels fun for students.
\end{abstract}

Keywords: Vocabulary, Snakes and Ladders Games, Teaching

\section{INTRODUCTION}

Everyday we use language in communication, because people requires language to convey the massage to others. In Indonesia, Bahasa is the national language while English is a foreign language. However, we are required to learn English for the sake of the nation's progress. The nation's progress can be achieved if its human resources quality. The quality of human resources one of which can be seen from the ability to understand and use the English language. This is because English is the international language that can be understood by almost all countries in the world. The tourist who come to Indonesia also use English eventhough they come from Hongkong, India, France and other countries. This proves that English has become the international languange. Globalizaation in all areas has put the English language as a communication tool between countries. English is also the "bridge" of science that can be learned by all students to develop science and technology. Thus, the English language has become the needs of all the community and students to face the global life. Therefore, learning English becomes important.

In learning English, the first thing students have to prepare is understand of meanings of words in the English language. So, the students have to learn much more vocabulary. Murcia (2001: 285) as cited in Parmawati (2018) states that vocabulary learning is central to language acquisition, whether the language is first, second, or foreign. Because vocabulary is the key to students understanding what they hear and read in school and to communicating successfully with other people. For this reason it is very important for them to quickly build up a large store of words.

To learning vocabulary in English lesson can be fun or bored for students. Learning process will become bored if students only pay attention to the teacher who just explain front of the class, but it will be interesting if students participated in it. The involvement of them in learning activities will improve their ability in learning. 
Unfortunately, teachers still difficult to encourage their students in learning because their students are shy to show their ability, large class, and the students are not accustomed to use English in their life. So the teachers should find techniques and ways so that the students can be active in learning English. The teachers can use games for techniques in learning. According to (Richards, J. C., \& Rodgers, 2001), "By using games teachers will create an atmosphere that will enhance the students' desire to learn the language. The students learn better when they have the feeling that they are making progress and games provide opportunity for students to practice and admit their fear". According to (Ersoz, 2000) who said that games are motivator in learning of language teaching because they are amusing and interesting they can give practices in language ability and can be used to practice to all types of communication.

According to (Wright, A. \& Betteridge, D. And Buckby, 1984), “The games provides a context for creating meaningful communication, this occurs when students try to understand how to play the games and when they communicate about the games. By doing games, students can communicative language practices as conventional exercises, but are more meaningful by using language that is often used in everyday life to convey information and opinions. By doing so, students are immersed in using the target language in all four skills, which assists them to better internalize a new language". There are hundreds types of games that can be used in English Languageteaching. One of the methods that can be used by techer to involvement students in learning activities is with use Snakes and Ladders Games. Therefore, the researcher was interested to conduct the research entitled "The Use of Snakes and Ladders Games in Teaching Vocabulary“.

Teaching is a process of communicating a subject or lesson. The teaching problem is the actual problem that is always followed by any teacher. The main factor that influence the student achievement is the way of the teacher to teach the subject or lesson to their student. (Brown, $\mathrm{H}$, 1994) says that teaching defined as showing or helping someone to learn how to do something. In addition, (Gage, 1964) also says "the teaching is guiding and facilitating learning, anabling the learner to learn setting the conditions for learning." Kimbly and Garmezy (1963:133) define that teaching is the activities to show or help someone to learn how to do something, give instructions, guide in the study of something, provide with the knowledge, cause to know, understand knowledge and give new knowledge.

From the statement above, teaching means giving instruction to the student to learn something which effect them in such a way that learning is facilitated and the student can acquire knowledge. So they will know or understand something.

Definition of Vocabulary

Definition of vocabulary toward (UR, 1996), "Vocabulary can be defined, roughly, as the words we teach in the foreign language. However, a new item of vocabulary may be more than just a single word: for example, post office, and mother-in-law, which are made up of two or three words but express a single idea. A useful convention is to cover all such cases by talking about vocabulary items rather than words."

\section{Kinds of Media}

To convey learning messages to students, usually teachers use teaching aids in the form of pictures, models, or other tools that can provide concrete experience, motivation to learn, and enhance absorption and learning retention. This is called learning media.

Understanding learning media in general can be interpreted as a tool for teaching and learning. Everything that can be used to stimulate thoughts, feelings, attention and abilities or skills. One function of learning media so that it can encourage the occurrence of effective learning 
processes. This limitation is quite extensive and deeply covers the understanding of sources, environment, people and methods used for learning or training purposes.

Learning media is also an instructional component that includes messages, people, and equipment. Namely a vehicle for learning information or message information. Learning media have many types. We can use various types of media that are available to support the learning process, especially in today's age the role of technology has been felt and has entered various aspects, including the world of education.

No wonder if there are now many educators and teachers teaching their students to use various kinds of learning media, examples of learning media commonly found such as projectors, videos, DVDs, games and so on. A teacher must be able to choose one of the learning media that will be used in the learning process. The use or selection of media must be adapted to the material and the learning objectives to be achieved. Learning media function, among others, is to attract students 'interest in the learning material presented, to improve students' understanding of the material presented and to present stronger and more reliable data.

Kinds of Learning Media According to Experts

The calisification and grouping of learning media is very diverse and differs between experts. For more details, refer to the following types of learning media according to experts and examples:

According to (Djamarah, 2002: 140)

a. Audiotive media, namely media that only rely on sound capabilities (radio, cassette recorders).

b. Visual media, namely media that only rely on the senses of vision because they only display still images (film, frame, photo, picture, or lukisa).

c. Audiovisual media are media that have sound elements and image elements. This type of media has better capabilities.

According to Sadiman, (2008: 28)

a. a.Graphic Media (visual media such as pictures / photos, sketches, diagrams, charts / charts, graphics, cartoons, posters, maps, and globe.

b. Media Audio that is related to the sense of hearing (radio, magnetic record recorder, language laboratory plate).

c. Silent Projection Media (frame films (slides), series of films (film strips), transparent media, films, television, videos).

According to Heinich (in Widyastuti and Nurhidayati, 2010)

a. Print / text media

b. Media exhibition / display

c. Audio media

d. Motion pictures

e. Multimedia

f. Web or internet based media

According to Rudy Bretz (1971)

a. Audio media

b. Print media

c. Media visually silent

d. Visual media motion

e. Semi-motion audio media

f. Semi-motion visual media

g. The audio visual media is silent 
h. Audio visual motion media

According to Kemp and Dayton in the Ministry of Education and Culture (2013: 3)

a. Print media

b. Media displayed (displayed media)

c. Overhead transparency (OHP)

d. Voice recording

e. Sound slides and film strips

f. Multi-picture presentation

g. Videos and films

h. Computer based instruction (computer based instruction)

According to Anderson (1976)

a. Audio (audio cassette, radio broadcast, $\mathrm{CD}$, telephone)

b. Print (textbooks, modules, brochures, leaflets, pictures)

c. Audio-printing (audio tapes with written material)

d. Silent visual projection: Overhead transparency (OHT), film frame (slide)

e. Silent audio-visual projection (sound slide frame movie)

f. Motion visual (silent film)

g. Audio visual motion (sound motion, video / VCD, television)

h. Physical objects (real objects, models, specimens)

i. Humans and the environment (teachers, librarians, laboratory assistants)

j. $\quad$ Computer (CAI)

According to Henrich, et al

a. Media that is not projected

b. Projected media

c. Audio media

d. Video media

e. Computer based media

f. Multi media kit

According to Azhar Arsyad (2011: 54)

1. Traditional media

a. projected silent visuals such as opaque projections, overhead projections, slides, filmstrips.

b. unprojected visuals such as pictures, posters, photos, charts, graphs, diagrams, exhibits.

c. audio such as disk recordings, cassette tapes.

d. ultimedia presentation such as slide plus sound (tape), multi-image projected dynamic visuals such as film, television and video

e. print such as text books, modules, workbooks, scientific magazines, hand-outs

f. games like puzzles, simulations, board games.

g. reality such as models, specimens (examples) and manipulatives.

2. Latest Technology Media

a. Telecommunications-based media such as teleconferencing, distance learning

b. micropocessor-based media such as computer-assisted instruction, computer games, intelligence, interactive, hypermedia, compact (video) disc systems.

According to Leshin et al (1992)

a. Human-based media (teachers, instructors, tutors, roles, group activities, field trips).

b. Print-based media (books, guides, exercise books, work aids, and loose sheets).

c. Visual-based media (books, charts, graphics, maps, images, transparencies, slides).

d. Audio-visual based media (video, film, slide tape program, television).

e. Computer-based media (computer-assisted teaching, interactive video, hypertext). 
According to Syaiful Bahri Djamaroh and S. Aswan Zain

1. Viewed from the type:

a. Auditive media are media that only rely on sound capabilities, such as: radio, cassette recorders, LPs.

b. Visual media is media that only relies on the sense of sight.

c. Audio visual media is media that has sound elements of the image.

2. Judging from its coverage, the media by Syaiful Bahri, et al. In the book Teaching and Learning Strategy, distinguished:

a. Media with extensive and simultaneous coverage

b. Media with coverage that is limited by space and place.

c. Media for individual teaching

3. Judging from the material making the media is divided into:

a. Simple media is media whose materials and manufacturing tools are easily available and cheap. The method of making is easy and its use is not difficult.

b. Complex media are materials and manufacturing tools that are difficult to obtain as well as expensive prices, and their use also requires adequate skills.

According to Seels and Glasgow

1. Traditional Media Choices

a. Projected silent visual

b. Unprojected visuals

c. Audio

d. Multimedia Presentation

e. Projected dynamic visuals

f. Print

g. Game

h. Reality

2. Latest Technology Media Choices

a. Telecommunication-based media

b. Microprocessor-based media

Types of Learning Media and Examples

By looking at the types of learning media according to the experts above, it can be concluded that there are several types of learning media such as the following:

1. Audio Media

Audio media serves to channel audio messages from the message source to the recipient of the message. Audio media is closely related to the sense of hearing. Judging from the nature of the message received, audio media can convey verbal messages (oral or words) and non-verbal (sounds and vocalizations). Examples of media: radio, tape recorder, telephone, language laboratory, etc.

Visual Media

2. Visual media is media that only relies on the sense of sight. Visual media displays the material using a projection device or projector, because through this media software that complements this projection tool will produce a bias light or image that matches the desired material. The message to be conveyed is poured into visual forms. In addition, the function of visual media also functions to attract attention, clarify the presentation of ideas, describe facts that might be easy to digest and be remembered if presented in visual form. Visual media is divided into two, namely silent visual media and visual media motion:

a. Media visual silence, for example photos, illustrations, flashcards, selected images and pieces of pictures, frame films, film, OHP, graphics, charts, diagrams, posters, maps, etc. 
b. Media visual motion, for example projection images move like silent films,etc.

\section{Audio Visual Media}

Audio visual media is a medium that is capable of displaying sound and images. Judging from the characteristics of the audio visual media can be divided into 2 namely silent audio visual media, and audio visual motion media. Silent audiovisual media including silent TV, soundtrack, voiceless pages, voiced books. Audio-visual motion media including TV movies, TV, sound films, sound pictures, etc.

\section{Various Media}

Multifunctional media is a media that is adapted to the potential of an area, around a school or in another location or in a community that can be used as a medium of teaching. Examples of various media include blackboard, three-dimensional media, reality, and learning resources for the community. The boards included in this media include: blackboards, bulletin boards, flannel boards, magnetic boards, electric boards, and nail boards. Three-dimensional media include: models, mock ups, and dioramas. Reality is real things as they are or are original. examples of the use of realities such as teachers carrying rabbits, birds, fish or by inviting students directly to the school garden or to the school farm.

Definition of Games

Games is types of learning media. According to (Arsyad, 2011) games is traditional media. Games are used to assist young learners during their language learning. They make classes entertaining and sustain effort and interest. They create an atmosphere of meaningful communication where young learners communicate before, during and after games (Wright, A. \& Betteridge, D. And Buckby, 1984).

From the definition of games above, that games can make the language learning process more enjoyable because it can attract the interest and enthuasiasm of young learners. Because from something interesting the young learners have desire to follow and include into game so communication will occurs before, during and after game.

Definition of Snakes and Ladders

Snakes and Ladders is an ancient Indian board game regarded today as a worldwide classic. It is played between two or more players on a gameboard having numbered, gridded squares. A number of "ladders" and "snakes" are pictured on the board, each connecting two specific board squares. The object of the game is to navigate one's game piece, according to die rolls, from the start (bottom square) to the finish (top square), helped or hindered by ladders and snakes respectively.

\section{METHOD}

Method is a style of conducting a research work which is determined by the nature of the problem (Singh, 2007). The research method of this study is descriptive research method. Descriptive research methods provide objective, reliable, and scientifically valid descriptions of what people think, say, and do. This research was applied on 26 February 2019. The participant is students of SDN Ngamprah Padalarang that consist of 27 students.

The data was collected by using a variety of sources such as observation, questionnaires and interview.

\section{RESULTS AND DISCUSSION}




\section{Results}

The results are interpreted and discussed by comparing the result of the observation, questionnaires and interview in the research.

\section{Observation}

The observation revealed that students are anthusiastic and seemed pleased with this games. Then, the students were given the questionnaires and interview at the end of the research. Questionnaires

The purpose of the questionnaires is to find out the students responses toward the use of snakes and ladders games in the class.

Interview

Interview was conducted to support the result from questionnaires and observation.

\section{Discussion}

Based on the data from observation, questionnaires and interview. It was revealed that the students gave positive and negative responses toward the use of snakes and ladders games in teaching vocabulary. As argued by Ahmadi (Ahmadi, 1999) that the students responses are divided into two categories they are positive responses and negative responses.

1. The Positive Responses

Related to the finding of the students response toward the use of snakes and ladders games, there are some point which are highlighted on the students show in the questionnaires and supported by observation and interview.

Based on the students answers on the questionnaires there are five points highlighted as positive responses. They are; The use of snakes and ladders games in teaching helped students improve vocabulary, increased students learning ability, students were motivated and students felt anthusiasm and students felt happy in learning process.

\section{The Negative Responses}

Based on the students answer on the questionnaires there are two points highlighted as negative response. They are: students found someone who dominate the group and a student found someine who cheated in games.

Data from the questionnaires got from student who answered the questions given. Data revealed what are the students response of snakes and ladders games can make improve their vocabulary. Data from the questionnaire were calculated with the frequency of the student who answered the questions given. The results of questionnaires were calculated using the formula below :

$$
\mathrm{P}=\text { fo }: \mathrm{n} \times 100 \%
$$

In which :

$\mathrm{P}=$ percentage

Fo $=$ frequency of abserved

$\mathrm{n}=$ number of sample

In analyzing the questionnaire, the number of sample or respondents answering "yes" and "no" were counted. The "yes" was counted as one and the "no" was counted as zero. After that, the result was shown in order to find out the students responses toward the use of snakes and ladders games in teaching vocabulary.

Table 1 Criterion on Student Response According to Sudjana (1984)

\begin{tabular}{l|c|c}
\hline No & Percentage $\%$ & Criterion \\
\hline
\end{tabular}




\begin{tabular}{c|c|c}
\hline 1 & 0 & None \\
\hline 2 & $1-25$ & Small number \\
\hline 3 & $26-49$ & Nearly half \\
\hline 4 & 50 & Half \\
\hline 5 & $51-75$ & More than half \\
\hline 6 & $76-99$ & Almost all \\
\hline 7 & 100 & All of \\
\hline
\end{tabular}

Table 2 Students Positive Responses According to Result of Questionnaire

\begin{tabular}{l|c}
\hline \multicolumn{1}{c|}{ Positive Responses } & Percentage (\%) \\
\hline Helped students improve vocabulary & 95 \\
\hline Increase students learning ability & 73 \\
\hline Students are motivated & 95 \\
\hline Students felt anthusiasm and happy & 91 \\
\hline
\end{tabular}

Table 3 Students Negative Responses According to Result of Questionnaire

\begin{tabular}{l|c}
\hline \multicolumn{1}{c|}{ Negative Responses } & Percentage (\%) \\
\hline Students found someone who dominate the group & 18 \\
\hline Students found someone who cheated in games & 4 \\
\hline
\end{tabular}

\section{CONCLUSION}

The aims of the study is to know what are the students responses toward the use snakes and ladders games in teaching vocabulary in sixth grade students of SDN 2 Ngamprah. The present study uses observation when start until end learning on one meeting, the result divided became two categories there are students positive responses and students negative responses. The result of questionnaires and interview showed the positive responses more than the negative responses. Most students agree that this game had helped them improve their vocabulary. They also more anthusiasm and having fun during the lesson. Furthermore, students got higher motivation in learning because the media used is very interesting for them. By use snakes and ladders games, students are easier to learn vocabulary and highly motivated in improving their english vocabulary.

\section{ACKNOWLEDGMENTS}

Appreciation and thanks the writer to lecturers, Anita Anngraeni, S.Sos., M.Pd. who has patiently acompanied the writer during the process of this research. Then, the writer also thanks to the participant of this research and IKIP Siliwangi supported received for the work being published.

\section{REFERENCES}

Ahmadi, A. (1999). Psikologi Perkembangan. Jakarta: Reinaka Cipta.

Arsyad, A. (2011). Media Pembelajaran. Jakarta: Rajawali Pers.

Brown, H, D. (1994). Principles of Language Learning and Teaching. Englewood Cliffs, N. J: Prentice Hall Regents.

Ersoz, A. (2000). Six Games for the EFL/ESL Classroom. VI. Retrieved from The Internet TESL Journal

Gage, N. (1964). Handbook of Research on Teaching. New York: Harper and Row. 
Parmawati, A. Using Magic Sentences Technique to Improve Students' Vocabulary (Classroom Action Research in the first Semester Stuents of IKIP Siliwangi Bandung.

Richards, J. C., \& Rodgers, T. S. (2001). Approaches and Methods in Language Teaching. Cambridge: Cambridge University Press.

Singh, K. (2007). Qualitative Social Research Method. New Delhi: Sage Publications.

UR, P. (1996). A Course in Language Teaching. Cambridge: Cambridge University Press.

Wright, A. \& Betteridge, D. And Buckby, M. (1984). Games for Language Learning. Cambridge: Cambridge University Press. 